\title{
PENGEMBANGAN LARUTAN DAUN BINAHONG SEBAGAI ANTISEPTIC MENGATASI MASTITIS PADA SAPI PERAH DI KELOMPOK TERNAK GIRI MUKTI, TASIKMALAYA
}

\author{
Dwi Wijayanti $^{\# 1}$, Firgian Ardigurnita ${ }^{* 2}$

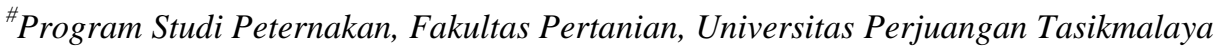 \\ Jalan Peta No 177, Kahuripan, Tasikmalaya, Jawa Barat, Indonesial \\ ${ }^{1}$ wijayantidwi12@gmail.com \\ * Program Studi Peternakan, Fakultas Pertanian, Universitas Perjuangan Tasikmalaya \\ Jalan Peta No 177, Kahuripan, Tasikmalaya, Jawa Barat, Indonesia 2 \\ ${ }^{2}$ firgian.peternakan. unper@gmail.com
}

\begin{abstract}
Abstrak
Tujuan dari pengabdian masyarakat ini adalah untuk menjadikan kelompok ternak Giri Mukti di desa Guranteng kecamatan Pageurageung kabupaten Tasikmalaya menjadi kelompok ternak dengan tingkat produktivitas dan reproduksi yang tinggi dengan penurunan penyakit mastitis. Tujuan khusus dari setiap rencana tahun pengabdian masyarakat adalah pengenalan, pengecekan status reproduksi dan pembuatan larutan daun Binahong sebagai antibakteri (mastitis). Metode yang digunakan adalah survey, transfer teknologi dan plot demonstrasi. Kegiatan ini diharapkan dapat menjadi salah satu alternative dalam penanggulangan, pencegahan gangguan reproduksi dan kesehatan khususnya mastitis dengan penggunaan tanaman herbal yaitu daun binahong. Permasalahan turunnya produksi susu, penyakit mastitis dan kurangnya perhatian peternak terhadap perkembangan sapi teratasi dengan obat antiseptic yang berasal dari daun binahong.
\end{abstract}

Kata Kunci — Daun Binahong, Mastitis, Teat Dipping dan Sapi Perah.

\section{PENDAhUluan}

Tingkat kemajuan suatu usaha peternakan sapi perah adalah peternakan yang memiliki aspek manajemen yang baik. Baik dalam manajemen reproduksi, pakan dan kesehatan. Kondisi kemajuan usaha peternakan dapat dilihat dari pengaturan sistem manajemennya. Industri peternakan sapi perah yang sudah maju dan besar selalu menerapkan manajemen yang baik dan benar. Karena manajemen yang baik menandakan usaha peternakan yang sudah maju. Berbeda dengan industri peternakan sapi perah skala kecil. Kelompok ternak giri mukti masih termasuk pada peternakan tradisonal pedesaan dengan konsep yang diterapkan masih bersifat sederhana. Manajemen kesehatan yang diterapkan masih belum baik atau bahkan kurang memenuhi standart yang ditentukan dalam pemeliharaan sapi perah. Manajemen reproduksi dan kesehatan adalah bagian penting usaha peternakan karena kesehatan ternak yang tinggi diikuti dengan manajemen reproduksi yang baik dapat menghasilkan efisiensi yang tinggi dengan produktivitas ternak yang tinggi pula [1]. Performa kesehatan pada sapi perah yang baik sangat tergantung dengan manajemen pemeliharaan, manajemen pemerahan dan manajemen kebersihan. Kelalaian atau sikap kurang perhatian saat proses pemerahan menyebabkan munculnya gangguan kesehatan pada sapi perah.

Gangguan kesehatan reproduksi salah satu nya yaitu mastitis. Mastitis adalah peradangan pada ambing akibat adanya bakteri [2]. Proses penanganan pemerahan terdiri dari awal pemerahan, proses pemerahan dan pasca pemerahan [3]. Permasalahan dalam penanganan pasca pemerahan yaitu kesalahan saat dipping membuat munculnya mastitis pada sapi perah. Selesai proses pemerahan saluran air susu pada puting beberapa saat masih terbuka sehingga kuman atau bakteri lebih mudah masuk ke dalam ambing.

Secara klinis radang ambing dapat berlangsung secara akut, subakut dan kronik. Radang dikatakan bersifat subklinis apabila gejala-gejala klinis radang tidak ditemukan saat pemeriksaan ambing. Pada proses radang yang bersifat akut, tanda-tanda radang jelas ditemukan, seperti: kebengkakan ambing, panas saat diraba, rasa sakit, warna kemerahan dan terganggunya fungsi. Air susu berubah sifat, menjadi pecah, bercampur endapan atau jonjot fibrin, reruntuhan sel maupun gumpalan protein. Proses yang berlangsung secara subakut ditandai dengan gejala sebagaimana di atas, namun derajatnya lebih ringan, ternak masih mau makan dan suhu tubuh masih dalam batas normal.

Mastitis dapat menyebabkan perubahan fisik, kimia, dan bakteriologi dalam susu serta perubahan patologi dalam jaringan glandula. Perubahan yang paling menonjol dalam susu meliputi perubahan warna, terdapat gumpalan dan munculnya leukosit dalam jumlah besar [4]. Mastitis merupakan penyakit radang ambing yang disebabkan oleh mikroorganisme terutama dalam bentuk bakteri, penyakit ini menimbulkan banyak kerugian pada 
peternakan sapi perah. Kerugian tersebut antara lain adalah adanya ongkos perawatan dan pengobatan, penurunan produksi susu dan penurunan kualitas susu [5].

Perlu dilakukan pencelupan puting menggunakan antiseptik agar dapat mencegah masuknya bibit penyakit yang dapat menyebabkan mastitis atau peradangan pada ambing. Pasca pemerahan secara dilapangan hanya dilakukan dengan penyemprotan air kran tanpa pemberian obat anti septic. Hal ini menyebabkan munculnya berbagai bakteri pemicu mastitis. Pencegahan mastitis dapat dilakukan dengan teat dipping menggunakan bahan bakterisida seperti iodine, chlorhexidine, dan chlorine setelah pemerahan [6]. Harga obat antiseptic yang digunakan dalam proses penanganan pasca pemerahan relative mahal membuat peternak sebagian tidak mampu membelinya. Penggunaan pinisilin dalam jangka panjang juga dapat meninggalkan residu pada puting sapi yang akhirnya akan mengontaminasi susu yang ada. Pemakaian antibiotik menimbulkan adanya residu antibiotik di dalam susu atau pada olahannya [7]. Mastitis yang dibiarkan tanpa penanganan berakibat fatal yaitu dapat menyebabkan produksi susu berhenti hingga putting ambing mengalami atresia. Hal ini berakibat dapat menggganggu kualitas produksi susu yang didapat. Gangguan kesehatan sapi berupa mastitis dapat menurunkan kualitas dan produksi susu, sehingga pendapatan peternak menurun. Sehingga perlu adanya alternative lain yang aramah lingkungan dengan harga terjangkau. Salah satunya penggunaan tamana herbal.

Tanaman Binahong adalah salah satu tanaman herbal yang memiliki khasiat sebagai anti mikroba, antibakteri dan antibody. Kandungan didalam daun Binahong seperti flavonoid, saponin, tannin, terpenoid dan alkaloid yang memiliki aktivitas antibakteri tinggi [8].

Tujuan dari pengabdian yang sudah dilakukan adalah kelompok ternak mengetahui jenis gangguan kesehatan dan penanganannya, mengetahui jumlah data ternak yang mengalami gangguan reproduksi dan kesehatan, serta penanganan awal untuk pembuatan larutan antibakteri yang berupa larutan daun binahong untuk gangguan reproduksi ambing (mastitis). Manfaat dari program pengabdian pengembangan masyarakat desa binaan yaitu: 1) dari sisi universitas sebagai mitra. Dalam hal ini lebih terfokus pada prodi peternakan dapat menjalankan salah satu tri darma perguruan tinggi yaitu melakukan pengabdian masyarakat melalui program desa binaan dengan membantu menyelesaikan masalah yang dihadapi oleh masyarakat guna meningkatkan usaha peternakan rakyat. 2. Sisi Kelompok Ternak Giri Mukti sebagai mitra. Kelompok mendapatkan keuntungan dengan adanya pemberian informasi dan pendampingan tentang pengelolaan manajemen reproduksi melalui pembuatan larutan antibiotic dan antibakteri yang diharapkan dapat mampu mengurangi gangguan reproduksi ternak di KTT Giri Mukti sehingga produksi ternak naik. 3. Dari sisi pengembangan ipteks. Teori yang dipelajari dan diteliti oleh Tim dapat diaplikasikan dan menunjang program pengabdian masyarakat pada desa binaan. 4. Dari sisi pengembangan materi pembelajaran. Hasil dan masalah yang muncul pada saat kegiatan pembenahan manajemen reproduksi kesehatan melalui teknologi ramah lingkungan (larutan daun binahong sebagai antiseptic alami pasca pemerahan) dapat digunakan sebagai materi pembelajaran dan penelitian, terutama untuk mengembangkan materi pembelajaran.

\section{TARGET DAN LUARAN}

Transfer teknologi dan pelatihan pembuatan larutan daun Binahong untuk antiseptic alami pasca pemeran pada sapi perah bertujuan membantu memecahkan permasalahan yang dihadapi oleh peternak untuk menangulagi gangguan reproduksi dan gangguan kesehatan (mastitis) dengan mengaplikasikan teknologi ramah lingkungan berbahan dasar daun binahong. Sasaran program ini adalah para peternak atau kelompok ternak sapi perah yang ada di Desa Guranteng Kecamatan Pagerageung Kabupaten Tasikmalaya propinsi Jawa Barat.

Target luaran dalam program diseminasi produk teknologi ke kelompok ternak Ternak Giri Mukti adalah berupa aplikasi teknologi larutan daun Binahong di Desa Guranteng Kecamatan Pagerageung Kabupaten Tasikmalaya propinsi Jawa Barat.

\begin{tabular}{|l|l|l|}
\hline \multicolumn{3}{|c|}{ Tabel 1. Rencana Target Capain Luaran } \\
\hline No & \multicolumn{1}{|c|}{ Jenis Luaran } & \multicolumn{1}{|c|}{$\begin{array}{c}\text { Indikator } \\
\text { Capaian }\end{array}$} \\
\hline 1 & Publikasi Ilmiah di Jurnal Nasional & Submitted \\
\hline 2 & $\begin{array}{l}\text { Peningkatan omzet pada mitra yang } \\
\text { bergerak dalam bidang ekonomi }\end{array}$ & Tidak ada \\
\hline 3 & $\begin{array}{l}\text { Peningkatan kuantitas dan kualitas } \\
\text { produk }\end{array}$ & Ada \\
\hline 4 & $\begin{array}{l}\text { Peningkatan pemahaman dan } \\
\text { ketrampilan masyarakat }\end{array}$ & Ada \\
\hline 5 & $\begin{array}{l}\text { Peningkatan ketentraman/kesehatan } \\
\text { masyarakat (mitra masyarakat } \\
\text { umum) }\end{array}$ & Tidak Ada \\
\hline 6 & $\begin{array}{l}\text { Jasa, model, rekayasa sosial, } \\
\text { sistem, produk/barang }\end{array}$ & Tidak Ada \\
\hline 7 & $\begin{array}{l}\text { Hak kekayaan intelektual (paten, } \\
\text { paten sederhana, hak cipta, merek } \\
\text { dagang, rahasia dagang, desain } \\
\text { produk industri, perlindungan } \\
\text { varietas tanaman, perlindungan } \\
\text { topografi. }\end{array}$ & \\
\hline 8 & Buku Ajar $\quad$ Tidak Ada \\
\hline
\end{tabular}

\section{METODE PELAKSANAAN}

Kegiatan yang dilakukan yaitu adalah survey, transfer teknologi dan plot demonstrasi. Survey 
meliputi proses pengecekan status reproduksi sapi perah, transfer teknologi berupa informasi mengenai penyakit mastitis dan manfaat daun binahong. Plot demonstrasi meliputi aplikasi proses pembuatan larutan daun binahong pasca pemeran sapi perah. 1) Pengecekan status reproduksi dilakukan melalui pengecekan kesehatan beberapa ternak dengan menggunakan peratan yang sederhana dan bantuan inseminator dan dokter hewan. 2) Prosedur pembuatan larutan daun binahong. Pembuatan larutan daun binahong mudah dilakukan karena menggunakan peralatan dan prosedur yang mudah. Pengecekan status reproduksi dan pembuatan larutan daun binahong untuk meningkatkan kesehatan ternak sehingga meningkat produktivitas ternak sapi perah di KTT Giri Mukti.

\section{Pengecekan Status Reproduksi dan Kesehatan} Sapi Perah

Pengecekan status reproduksi pada sapi perah dilakukan dengan bantuan inseminator dan dokter hewan. Pengecekan yang dilakukan berupa pemeriksaan fisik dan kondisi fisiologis pada sapi perah. Proses pengecekan status reproduksi dan kesehatan sapi perah diperlukan beberapa alat dan bahan.

Alat yang dibutuhkan untuk pemeriksaan reproduksi dan kesehatan sapi perah:

1. Alat tulis yang digunakan untuk mencatat hasil pengamatan.

2. Termometer untuk mengukur suhu badan sapi.

3. Kamera untuk medokumentasikan.

4. Stopwach untuk menghitung.

Bahan yang dibutuhkan untuk pemeriksaan reproduksi dan kesehatan sapi perah:

1. Ternak sapi perah

2. Vitamin dan obat-obatan Cara pemeriksaan reproduksi dan kesehatan sapi perah:

\section{Gejala Klinis}

Radang dikatakan bersifat sub klinis apabila gejalagejala klinis radang tidak ditemukan saat pemeriksaan ambing.

Tanda-tanda radang jelas ditemukan, seperti:

a. Kebengkakan ambing, panas saat diraba, rasa sakit, warna kemerahan dan terganggunya fungsi.

b. Air susu berubah sifat, seperti: pecah, bercampur endapan atau jonjot fibrin, reruntuhan sel maupun gumpalan protein.

c. Proses yang berlangsung secara sub akut ditandai dengan gejala sebagaimana di atas, namun derajatnya lebih ringan sebab ternak masih mau makan dan suhu tubuh masih dalam batas normal.

d. Proses berlangsung kronis apabila infeksi dalam suatu ambing berlangsung lama, dari suatu periode laktasi ke periode berikutnya. Proses kronis biasanya berakhir dengan atropi kelenjar mammae.

\section{DIAGNOSIS}

Pengamatan secara klinis adanya peradangan ambing dan puting susu, serta perubahan warna air susu yang dihasilkan.

\section{Pengecekan Status Fisiologi Dan Tingkah Laku}

1. Menyiapkan ternak yang diamati.

2. Mengamati ternak yang sudah disiapkan dan mencatat hasil pengamatan tersebut.

3. Melakukan pemeriksaan secarah menyeluruh

4. Mengukur suhu tubuh ternak dibagian anus dapat menggunakan thermometer manual dengan memasukan kedalam rectum kira-kira $10 \mathrm{~cm}$ sejajar tulang belakang.

5. Memeriksa nafas ternak dengan penggung tangan dan memperhatikan gerakan pernafasan dari gerakan perut.

6. Memeriksa denyut jantung/pulsus ternak dapat dilakukan dibagian ketiak kaki kiri bagian depan (Arteri Medialis), pada bagian mendibula (Arteri Facialis), atau bagian ekor (Arteri Coccygealis) kira-kira $10 \mathrm{~cm}$ dari pangkal ekor.

Proses Pembuatan Larutan Daun Binahong Pembuatan larutan daun binahong sebagai alternative dalam mengganti antibiotic pasca pemerahan sapi Perah. Proses pembuatan kefir diperlukan beberapa alat dan bahan.

Alat yang dibutuhkan untuk pembuatan larutan daun binahong:

1. Ember

2. Kain bersih

3. Penggiling (blender)

4. Lemari pendingin

5. Sarung tangan

Bahan yang dibutuhkan untuk pembuatan larutan daun binahong:

1. Aquades

2. Daun binahong

Cara pembuatan larutan daun binahong:

1. Daun binahong (Anredera cordifolia) sebanyak $1 \mathrm{~kg}$ dibersihkan dari kotoran.

2. Daun binahong yang sudah bersih dilembutkan atau digiling dengan menggunakan blender.

3. Hasil gilingan yang sudah lembut dicampur dengan aquades.

4. Daun binahong yang sudah tercampur dengan aquades diletakkan di ember untuk digunakan sebagai dipping pasca pemeran sapi perah.

5. Sisa larutan yang masih ada dapat disimpan dalam lemari es supaya dapat digunakan kembali. 


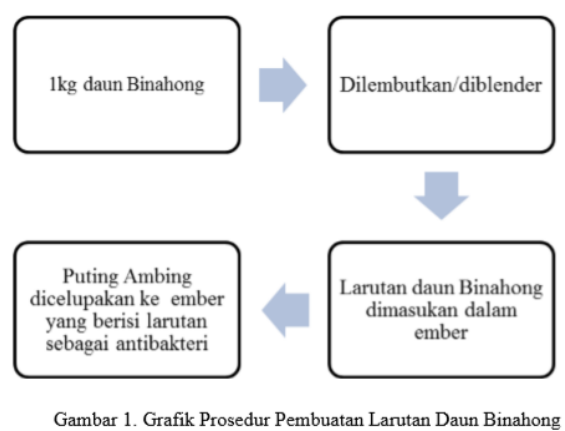

Cara Dipping yang benar :

1. Ember yang telah berisi larutan daun binahong disiapkan untuk bahan cuci dipping.

2. Sarung tangan yang sudah disiapkan dipakai gunanya untuk menjaga agar tetap steril.

3. Putting dicelupkan didalam larutan daun binahong yang sudah disiapkan diember atau di baskom.

4. Putting yang sudah dicelupkan dalam larutan daun binahong kemudian dikeringkan dengan menggunakan kain bersih.

Guna membantu menyelesaikan permasalahan yang dihadapi oleh mitra selama ini, maka solusi yang ditawarkan adalah melakukan survey, transfer teknologi dan demonstrasi plot yang berkaitan dengan masalah mitra tersebut. Kegiatan yang dilakukan 2 kegiatan yaitu proses pengecekan status reproduksi sapi perah dan proses pembuatan larutan daun binahong. 1) Pengecekan status reproduksi dilakukan melalui pengecekan kesehatan beberapa ternak dengan menggunakan peratan yang sederhana dan bantuan inseminator dan dokter hewan. 2) Prosedur pembuatan larutan daun binahong. Pembuatan larutan daun binahong mudah dilakukan karena menggunakan peralatan dan prosedur yang mudah. Pada kesempatan kali ini dibahas pengecekan status reproduksi dan pembuatan larutan daun binahong untuk meningkatkan kesehatan ternak sehingga meningkat produktivitas ternak sapi perah di KTT Giri Mukti.

Diharapkan hasil kegiatan ini dapat menjadi suatu motivator bagi kelompok ternak dan peserta lainnya dalam mengembangkan usaha peternakan serta upaya memperbaiki produktivitas ternak secara mandiri. Selanjutnya teknologi yang telah dimiliki tersebut dapat disebarluaskan kepada masyarakat lain sehingga usaha peternakan berkembang menjadi lebih baik.

\section{HASIL DAN PEMBAHASAN}

Dalam proses pelaksanaan pembuatan larutan daun Binahong sebagai obat antibakteri alami pasca pemeran pada sapi perah terlebih dahulu dilakukan transfer teknologi tentang pentingnya pengetahuan mengenai penyakit mastitis dan manfaat daun binahong.

\section{Transfer Teknologi Larutan Daun Binahong dalam Upaya Penanganan Mastitis}

Pemberian informasi mengenai gambaran penyakit mastitis pada sapi perah sebenarnya, penyebab dan cara penanganannya. Peserta yang hadir adalah kepala Desa Guranteng, ketua Koperasi Susu Sapi (KSS), perwakilan dari Dinas Pertanian, ketua Kelompok Ternak dan anggota kelompok ternak Desa Guranteng. Materi transfer teknologi dalam bentuk pemaparan berupa power point. Hasil pengamatan selama transfer teknologi berlangsung menunjukkan bahwa mitra dan anggota kelompok tani ternak Giri Mukti sangat antusias dalam mengikuti kegiatan tersebut. Hal ini terlihat dari banyaknya pertanyaan yang diajukan selama acara berlangsung.

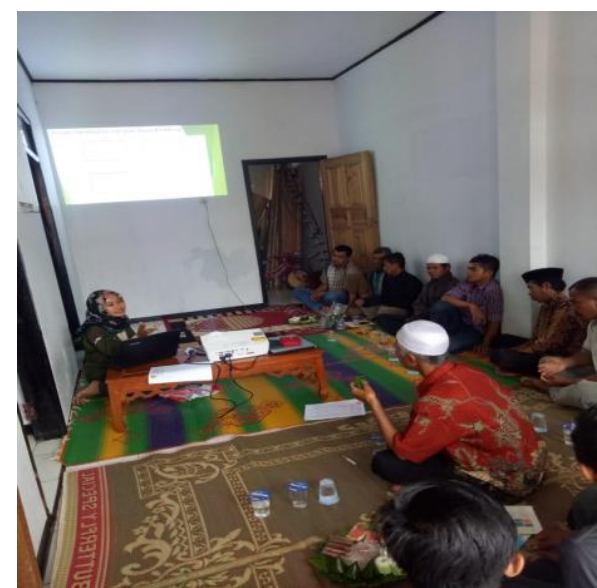

Gambar 2. Proses Transfer Teknologi Kegunaan Larutan Daun Binahong

Berdasarkan cerita dan pemaparan kondisi saat dipping dari peternak mastitis disebabkan karena kotornya kondisi kandang, manajemen pasca pemerahan yang masih belum baik. Menurut Pyorala and Taponen [4], penyebab dari mastitis adalah adanya bakteri Staphylococcus aureus dan Streptococcus agalactiae. Penularan bakteri ini adalah masuk melalui puting dan kemudian berkembangbiak di dalam kelenjar susu. Hal ini terjadi karena puting yang habis di perah, terbuka, kemudian kontak dengan lantai atau tangan pemerah mengandung bakteri. Peternak di Giri Mukti biasanya pasca pemerahan hanya menggunakan air yang mengalir dalam membersihkan putting sapi perah dan dalam kondisi tangan peternak yang belum tentu higienis.

Menurut Sugiri dan Anri [2], kerugian penyakit mastitis adalah kerugian ekonomi yang diakibatkan mastitis subklinis berupa (1) penurunan produksi air susu per kuartir per hari antara 9-45,5\%; (2) penurunan kualitas air susu yang mengakibatkan penolakan air susu mencapai $30-40 \%$, penurunan 
kualitas hasil olahan air susu; dan (3) peningkatan biaya perawatan dan pengobatan serta (4) pengafkiran ternak lebih awal.

\section{Penerapan Langsung Penggunaan Larutan Daun Binahong dalam Pasca Pemerahan}

Penerapan langsung proses dipping dengan menggunakan larutan daun binahong oleh salah satu peternak. Peternak memiliki keinginan yang kuat untuk mengembangkan sapi perahnya. Sehingga ketika saya mengajak mereka untuk praktek langsung ke kandang mereka antusias. Keinginan mereka untuk menyembuhkan gangguan mastitis pada sapi mereka terhalang karena biaya pembelian obat yang harga nya mahal. Adanya transfer teknologi berupa tanaman herbal daun Binahong yang mudah dikembangkan dan gratis merupakan solusi bagi mereka dalam gangguan mastitis yang selama ini mereka alami.

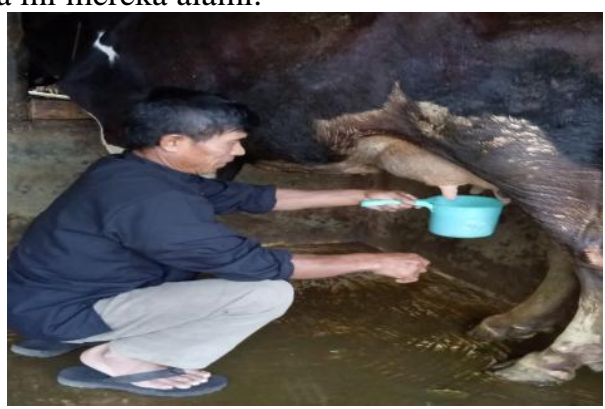

Gambar 3. Proses Dipping Menggunakan Larutan Daun Binahong

Kemudahan dalam membuat larutan daun binahong menjadi alternative terbaik buat peternak. Daun binahong yang masih segar dilembutkan atau dihancurkan sampai keluar lendir kemudian dicampurkan sedikit air untuk mengencerkan agar dapat digunakan sebagai dipping. Manfaat dari daun binahong sudah terbukti dalam menyembuhkan luka dan sebagai obat dalam mempercepat munculnya estrus postpartum. Kandungan daun binahong berupa flavonoid, saponin, tannin, terpenoid dan antioksidan. Antioksidan dapat menangkal radikal bebas yang dapat merusak kelenjar membrane sel sehingga perkembangan tidak terhambat.

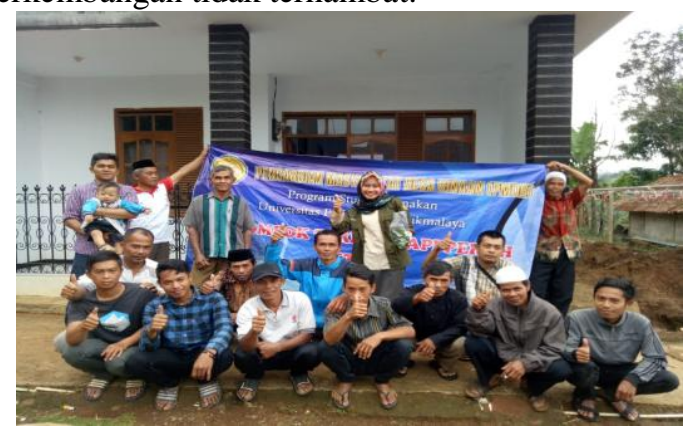

Gambar 4. Foto Bersama Transfer Teknologi Sebagian Peserta Kelompok Ternak Giri Mukti

\section{KESIMPULAN}

Pelaksanaan kegiatan ini berhasil baik dimana antusiasme dari mitra dan anggota kelompok ternak Giri Mukti dalam mengikuti kegiatan ini cukup besar. Pemahaman penggunaan tanaman herbal daun binahong dapat mengatasi gangguan mastitis. Permasalahan turunnya produksi susu, penyakit mastitis dan kurangnya perhatian peternak terhadap perkembangan sapi teratasi dengan obat antiseptic yang berasal dari daun binahong.

\section{UCAPAN TERIMA KASIH}

Terimakasih kepada Lembaga Penelitian dan Pengabdian Masyarakat (LP2M) Universitas Perjuangan Tasikmalaya adanya program Hibah Internal yang telah mendanai kegiatan PMDB tahun 2018 dan Kelompok Ternak Giri Mukti Pageurageung Kabupaten Tasikmalaya.

\section{DAFTAR PUSTAKA}

[1] Reswati, Jaswandi dan E. Nurdin. 2014. Performa Reproduksi Sapi Perah di Sumatera Barat Reproduction Performance of Dairy Cows in West Sumatra. Jurnal Peternakan Indonesia. 16 (3):157165.

[2] Sugiri, Y.D. dan A. Anri. 2010. Prevalensi patogen penyebab mastitis sub klinis (Staphylococcus aureus dan Streptococcus agalactiae) dan patogen penyebab mastitis subklinis lainnya pada peternak skala kecil dan menengah di beberapa sentra peternakan sapi perah di Pulau Jawa.

[3] Suryowardojo, P. 2012. Penampilan kandungan protein dan kadar lemak susu pada sapi perah mastitis Friesian Holstein. J. Experimental Life Sci. 2: 42-48.

[4] Pyorola, S. and S. Taponen. 2009. Coagulasenegative Staphylococci emerging mastitis pathogen. Veterinary Microbiology. 134: 3-8.

[5] Kurniawan, I., S. Sarwiyono, dan P. Surjowardojo. 2013. Pengaruh teat dipping menggunakan dekok daun kersen (Muntingia calabura L.) terhadap tingkat kejadian mastitis. Jurnal Ilmu-Ilmu Peternakan. 23: 27-31.

[6] Karlina C.Y., Ibrahim M., Trimulyono G. 2013. Aktivitas antibakteri ekstrak herba krokot (Portulaca oleracea L.) terhadap Staphylo-coccus aureus dan Escherichia coli.E. Journal UNESA Lentera-Bio. 2 (1): 87-93.

[7] Abrar, M., I W. T. Wibawan, B. P. Priosoeryanto, M Soedarwanto, dan F. H. Pasaribu. 2012. Isolasi dan karakterisasi hemaglutinin Staphylococcus aureus penyebab mastitis subklinis pada sapi perah. Jurnak Kedokteran Hewan. 6 : 16-21.

[8] Wijayanti, D., E.T.Setiatin, and E. Kurnianto. 2017. Study on postpartum estrus of guinea pigs (Cavia cobaya) using Anredera cordifolia leaf extract. Vet.Word. 10(4):375-379. 